\title{
National survey of the oral health of 12- and 15-year-old schoolchildren in the United Arab Emirates
}

M.A.I. El-Nadeef, ${ }^{1}$ E. Al Hussani, ${ }^{2}$ H. Hassab ${ }^{2}$ and I.A. Arab ${ }^{3}$

$$
\begin{aligned}
& \text { المسح الوطني لصحة الفم لأطفال المدارس بأعمار } 12 \text { و15 عاماً في الإمارات العربية المتحدة }
\end{aligned}
$$

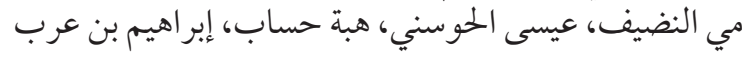

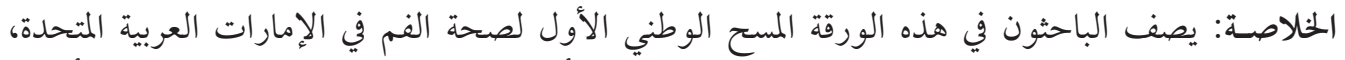

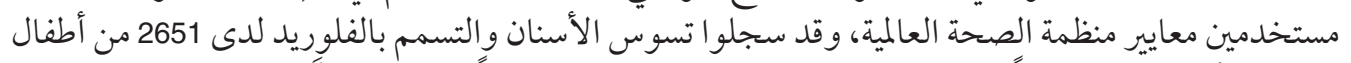

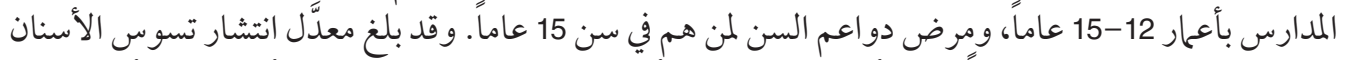

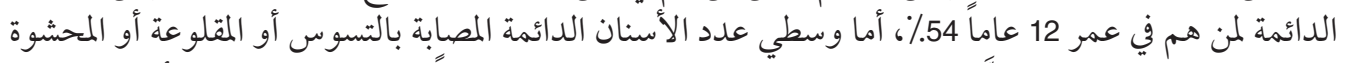

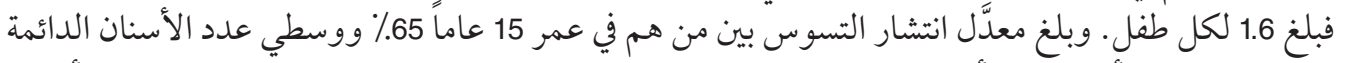

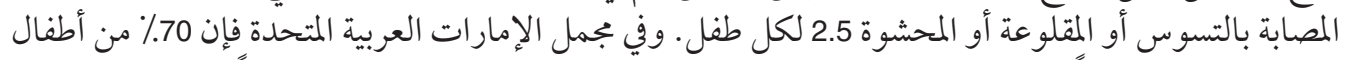

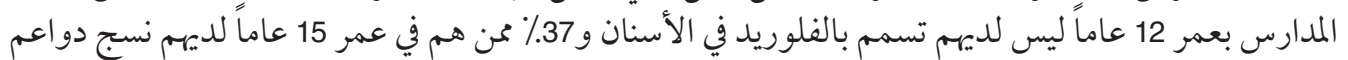
الأسنان تتمتع بالصحة.

ABSTRACT This paper describes the first national survey of oral health in the United Arab Emirates (UAE). Using WHO criteria, dental caries and fluorosis were recorded in 2651 schoolchildren aged 12 and 15 years, and periodontal disease in those aged 15 years. The prevalence of dental caries in the permanent teeth of 12-year-olds was 54\%; the mean DMFT (number of decayed, missing or filled permanent teeth) per child was 1.6. The prevalence of dental caries in 15 -year-olds was $65 \%$ and the mean DMFT was 2.5. For the UAE as a whole, $70 \%$ of 12 -year-old schoolchildren had no dental fluorosis and $37 \%$ of 15 -year-olds had healthy periodontal tissues.

Étude nationale sur la santé bucco-dentaire des enfants de 12 et 15 ans scolarisés aux Émirats arabes unis

RÉSUMÉ Cet article est consacré à la première enquête nationale sur la santé bucco-dentaire aux Émirats arabes unis (ÉAU). En se basant sur les critères de l'OMS, on a enregistré les caries dentaires et la fluorose chez 2651 enfants scolarisés âgés de 12 et 15 ans, et les parodonpathies chez ceux âgés de 15 ans. La prévalence des caries sur les dents définitives chez les enfants âgés de 12 ans était de $54 \%$; l'indice CAO (nombre de dents définitives cariées, absentes ou obturées) moyen par enfant était de 1,57. La prévalence des caries dentaires chez les adolescents âgés de 15 ans était de $65 \%$ et l'indice CAO moyen de 2,47. Dans l'ensemble des ÉAU, $70 \%$ des écoliers de 12 ans ne présentaient pas de fluorose dentaire et $37 \%$ de ceux âgés de 15 ans avaient des tissus parodontaux sains.

${ }^{1}$ Preventive Dentistry Section; ${ }^{3}$ Dental Department, Ministry of Health, Dubai, United Arab Emirates (Correspondence to M.A.I. El-Nadeef: nuraini@emirates.net.ae).

2Dental Department, General Health Authority, Abu Dhabi, United Arab Emirates.

Received: 19/10/06; accepted: 26/02/07

المجلة الصحية لشرق المتوسط، منظمة الصحة العالمية، المجلد الخنامس عشر، العدد ع، 9 +. 


\section{Introduction}

The United Arab Emirates (UAE) is a young nation, created by the federation of 7 Emirates just over 30 years ago. Development has been rapid, with corresponding changes in the wealth and lifestyle of the diverse population. Previous dental surveys have usually been confined to a single Emirate [unpublished reports: 1991, K. Cowles, E. Beltran; 1993, D. Barmes; 1994, H. Tala], and subjects were often chosen by convenience rather than by random sampling, although these surveys were sufficient to indicate an increasing problem of dental decay in young schoolchildren in the Emirates. Therefore, it was important that this survey included a sample of schoolchildren from all 7 Emirates and all 9 medical districts within these Emirates.

It is hoped that this report will be valuable in several ways. First, it should assist those responsible for planning health and oral health services in the UAE by providing a picture of the severity and distribution of oral disease in children. Secondly, it will provide a baseline against which trends in the oral health of children in the UAE can be recorded. These trends will indicate the degree of success of oral health care strategies and will assist in the planning of new strategies. Thirdly, it will provide dental practitioners with a profile of the state of children's teeth in the UAE to assist in the evaluation of their patients and, fourthly, the findings will contribute to the world database of oral health and disease, maintained by the World Health Organization (WHO): the Global Oral Data Bank.

The aims of this survey were to provide information on the oral health of schoolchildren to assist in the planning of preventive and treatment oral care services in the UAE; to provide baseline information on the oral health of schoolchildren in the UAE in order to determine future trends in oral disease; to determine the variation in oral disease in schoolchildren in different medical districts in the UAE; and to compare the oral health of schoolchildren in the UAE with the oral health of similarly aged schoolchildren in some other countries.

\section{Methods}

\section{Study design}

A total of 2651 schoolchildren were examined: 1323 aged 12 years and 1328 aged 15 years. Dental caries and fluorosis was recorded in both age groups, 12 and 15 years, and periodontal disease only in those aged 15 years. Descriptive statistics were derived for standard oral health indices, by age, sex and district and for UAE nationals and nonnationals. A recording clerk assisted each examiner and the role of organization clerk was given to the school nurse to ensure a constant flow of children. The examiner was asked to review each day's recording forms for completeness and clarity of recording. During the course of the survey, the school nurse was requested to arrange for the re-examination of $10 \%$ of children, to assess examiner reproducibility.

\section{Sampling}

Schoolchildren aged 12 and 15 years in all 9 medical districts were included. Sampling was in 2 stages. First, all state and private schools in each medical district were listed; the small number of "community schools" (e.g. American and Canadian schools) were excluded. Secondly, within each selected school, children were chosen with a frequency depending on the size of the school, giving each child in a district an equal probability of being selected. After calculating the sampling interval within each school, dates of birth were checked to 
ensure eligibility and the first name from the school register list was selected using random number tables. It was decided not to replace schoolchildren who, for a variety of reasons, were not examined.

The sample size was determined in the following way. Guidelines for conducting oral health surveys published by the WHO suggest that the number of subjects in each unit of analysis (cell size) should be at least 50 [1]. The intention was to present descriptive statistics for boys and girls separately in each of the 9 medical districts within the UAE. It was, therefore, decided to sample about 150 schoolchildren in each medical district to allow for some non-participation. Thus, about 1350 schoolchildren for each of the age groups would be sampled. The size of the population within each of the 9 medical districts differs considerably so the proportion of eligible schoolchildren who were to be sampled varied between medical districts. This meant that in order to obtain descriptive statistics for the whole of the country, mean scores for each medical district had to be weighted appropriately.

\section{Permission and consent}

The survey proposal was approved by the Ministries of Health and Education. Approval was then obtained from the appropriate authorities in each medical district, and lists of schools and the numbers of schoolchildren in the relevant age groups were compiled. After selection of individual children, verbal consent was sought from the parents for the child's examination. Only schoolchildren whose parents consented were examined.

\section{Standardization of examiners}

The 9 examiners examined schoolchildren in their own medical districts in order to reduce differences in examination standards between examiners and to adhere to WHO guidelines. Two 1-week training sessions were conducted before the examination of subjects started. Schoolchildren aged 12 and 15 years were examined by all examiners and the findings were compared and discussed. During the main survey, each examiner re-examined a $10 \%$ sample of schoolchildren in order to assess examiner reproducibility [2]. As far as possible, the organizing clerk concealed the identity of these re-examined subjects from the examiner.

\section{Examination of subjects and logistic support}

Each examining team was responsible for the arrangements to examine the selected subjects within their medical districts. Whenever possible, a medical or dental room or similar alternative was used. The children were examined in a supine position on a flat table. The examiner was seated and the recorder was seated close to the examiner to ensure accurate recording. All examinations were carried out under natural and artificial room light, but without a spotlight. No special tooth-cleaning was done before examination; teeth were dried with cotton gauze before examination if needed. Compressed air was not used. No drying was carried out before the recording of dental fluorosis. The order of examination was: presence of teeth and caries status, dental fluorosis, periodontal disease. If the reason for a tooth being missing was not clear to the examiner, the subject was questioned to aid the decision. The examination recording form was a modification of the WHO form [1]. Identification numbers were allocated to subjects and examiners.

\section{Examination criteria}

Each tooth was examined in turn. A tooth was deemed to be present if any part of the crown was visible. "Decay" was re-

المجلة الصحية لشرق المتو سط، منظمة الصحة العالمية، المجلد الخامس عشر، العدد ع، 9 +. 
corded at one level of severity only-the cavitation stage (detectable softened floor, undermined enamel or softened wall) — and sticky fissures or precavitation lesions were recorded as sound. The examination was principally visual. The explorer was used for removal of plaque and debris, and as a diagnostic aid for approximal and fissure sites. "Excluded tooth" was used when the tooth could not be examined. "Sealed tooth" was recorded as such. For missing permanent teeth, a tooth was recorded as "missing" unless it appeared to be unerupted or an incisor tooth that was missing due to trauma or a permanent premolar tooth that had been extracted for orthodontic reasons; the child could be questioned about these.

\section{Dental fluorosis}

Dean's criteria [3], as described in the WHO guidelines [1], were used to record dental fluorosis in the permanent teeth of both the 12 - and 15 -year-olds: $0=$ normal, $1=$ questionable, $2=$ very mild, $3=$ mild, $4=$ moderate, $5=$ severe. All teeth were examined and the mouth score was the score given to the most severely affected tooth.

\section{Periodontal disease}

The Community Periodontal Index of Treatment Needs (CPITN) described by WHO [1] was used to record gingival bleeding and dental calculus in the 15 -year-olds. The mouth was divided into sextants (teeth 18$14,13-23,24-28,38-34,33-43,44-48)$. The following index teeth were examined: $16,11,26,36,31$ and 46.

If any of these teeth were absent, other teeth in the sextant were examined and the highest score in that sextant was recorded. A WHO periodontal probe with $0.5 \mathrm{~mm}$ diameter tip was used to examine all of the gingival margins of each tooth. There should be a minimum of 2 teeth present in the sextant which are not indicated for extraction; if this was not the case, the sextant was not recorded. The codes were: $0=$ healthy, 1 = bleeding on probing, 2 = presence of supra- and/or sub-gingival calculus.

\section{Data handling and analysis}

The following derived variables were calculated for each subject:

- number of decayed teeth (DT), missing teeth (MT), filled teeth (FT) and decayed, missing, filled teeth (DMFT);

- highest dental fluorosis score for any tooth in the mouth;

- highest CPITN score for any sextant in the mouth.

For each group of schoolchildren, the following descriptive statistics were calculated:

- percent prevalence of health/disease;

- mean number of teeth affected by dental caries per mouth (as a measure of caries severity).

Examiner reproducibility was expressed as the reliability coefficient for the DMFT (12- and 15-year-olds) index [2], calculated for each examiner. The values for the 9 examiners were averaged to produce an estimate of reliability for the examination of all schoolchildren.

\section{Results}

There was a high response rate $(96.7 \%$ of those sampled), so the total number of schoolchildren examined in the survey was 2651. This represented $5 \%$ of 12 -year-olds and $5 \%$ of 15 -year-olds attending schools in the UAE. More girls were examined in both age groups (Table 1). The proportion of those examined who were non-UAE nationals increased with age, reaching about one-third in 15 -year-olds. The proportion 
Eastern Mediterranean Health Journal, Vol. 15, No. 4, 2009

\begin{tabular}{|c|c|c|c|c|c|c|c|c|}
\hline \multirow[t]{3}{*}{ Medical district } & \multicolumn{4}{|c|}{12 years } & \multicolumn{4}{|c|}{15 years } \\
\hline & \multicolumn{2}{|c|}{ Boys } & \multicolumn{2}{|c|}{ Girls } & \multicolumn{2}{|c|}{ Boys } & \multicolumn{2}{|c|}{ Girls } \\
\hline & No. & $\%$ & No. & $\%$ & No. & $\%$ & No. & $\%$ \\
\hline Abu Dhabi & 74 & 50 & 75 & 50 & 75 & 50 & 75 & 50 \\
\hline Al Ain & 73 & 46 & 87 & 54 & 71 & 42 & 78 & 52 \\
\hline Western Region & 50 & 40 & 74 & 60 & 49 & 37 & 82 & 63 \\
\hline Dubai & 95 & 63 & 56 & 37 & 44 & 29 & 108 & 71 \\
\hline Sharjah & 60 & 40 & 90 & 60 & 85 & 51 & 83 & 49 \\
\hline Ajman & 16 & 11 & 134 & 89 & 49 & 33 & 101 & 67 \\
\hline Um Al Quwain & 53 & 35 & 97 & 65 & 53 & 34 & 104 & 66 \\
\hline Ras Al Khaimah & 20 & 15 & 118 & 85 & 42 & 30 & 97 & 70 \\
\hline Fujairah & 71 & 47 & 80 & 57 & 54 & 41 & 78 & 59 \\
\hline Total & 512 & 39 & 811 & 61 & 522 & 39 & 806 & 61 \\
\hline
\end{tabular}

of 12- and 15-year-old children examined was $71 \%$ and $65 \%$ for UAE nationals and $29 \%$ and $35 \%$ for non-UAE nationals respectively. The most common countries of origin of the non-UAE nationals were Egypt, Palestine, Syria and Jordan.

\section{Dental caries in 12-year-olds}

The prevalence and severity of caries experience in 12-year-old schoolchildren is given in Table 2. The proportion of 12-year-olds who had caries in their permanent dentition was $54 \%$ overall, varying between $43 \%$ in Sharjah and Umm Al Quwain and 89\% in Western Region (Table 2). The DMFT distribution by tooth of these schoolchildren is given in Figure 1.

A very high proportion $(32 \%)$ of 12 year-olds in Western Region had more than 4 teeth with decay. On the other hand, in 4 medical districts (Ajman, Dubai, Sharjah and Um Al Quwain) 3\% or less of school-

\begin{tabular}{|c|c|c|c|c|c|}
\hline \multirow[t]{3}{*}{ Medical district } & \multicolumn{3}{|c|}{$\%$ of children } & \multicolumn{2}{|c|}{ Mean DMFT } \\
\hline & $\begin{array}{l}\text { Caries- } \\
\text { free }\end{array}$ & $\begin{array}{l}\text { Moderate } \\
\text { caries }\end{array}$ & $\begin{array}{l}\text { High } \\
\text { caries }\end{array}$ & & \\
\hline & DMFT 0 & DMFT 1-4 & DMFT > 4 & Boys & Girls \\
\hline Abu Dhabi & 40 & 50 & 10 & 1.8 & 2.1 \\
\hline Al Ain & 34 & 57 & 9 & 2.0 & 1.9 \\
\hline Western Region & 11 & 58 & 31 & 3.0 & 4.2 \\
\hline Dubai & 52 & 46 & 2 & 1.2 & 0.7 \\
\hline Sharjah & 57 & 39 & 3 & 0.9 & 0.9 \\
\hline Ajman & 53 & 45 & 1 & 1.5 & 1.0 \\
\hline Um Al Quwain & 57 & 40 & 3 & 1.1 & 0.9 \\
\hline Ras Al Khaimah & 50 & 42 & 8 & 1.7 & 1.3 \\
\hline Fujairah & 34 & 60 & 5 & 1.4 & 2.1 \\
\hline
\end{tabular}

المجلة الصحية لشرق المتوسط، منظمة الصحة العالمية، المجلد الخامس عشر، العدد ع، 9 +. 
children had more than 4 teeth with decay (Table 2).

For the whole of the UAE, $8 \%$ of these schoolchildren had had teeth extracted because of dental caries and $18 \%$ had had teeth filled. The highest number of extractions was in Fujairah and of fillings was in Abu Dhabi. For the whole of the UAE, the mean DMFT for 12-year-olds was 1.6. The filled component was $0.5 \mathrm{FT}$ and the extracted component was $0.1 \mathrm{MT}$.

The high rate of caries in Western Region in 12-year-olds was accompanied by a low number of teeth filled or extracted.

There was little difference between the sexes in mean DMFT and in the components (DT, MT and FT) of this index of caries (Table 2). Caries experience was higher in the girls in Western Region (mean 4.2 DMFT) and lowest in girls in Dubai (0.7 DMFT). There was also little difference in mean DMFT between UAE nationals (1.6 DMFT) and non-UAE nationals (1.4 DMFT): the filled (FT) and the extracted (MT) components were also similar. The prevalence of 1 or more sealed teeth in 12year-olds in the UAE was $0.1 \%$.

\section{Dental caries in 15-year-olds}

The prevalence and severity of dental caries in 15 -year-olds is given in Table 3. By the age of 15 years, $65 \%$ had experienced dental decay in the UAE overall. This varied from $51 \%$ in Sharjah to $89 \%$ in Western Region. The DMF distribution by tooth of these children is given in Figure 2.

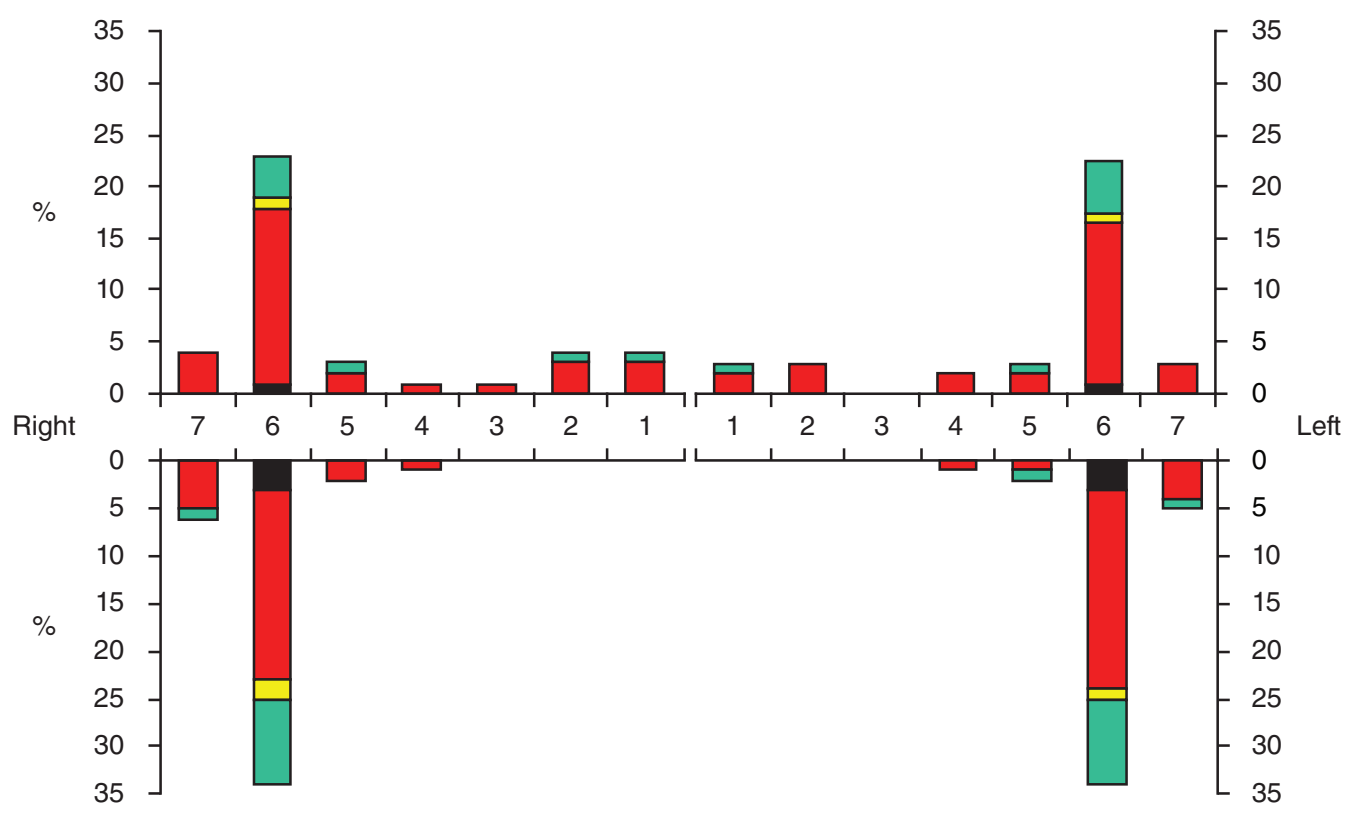

$\square F \quad \square D F \quad \square D \quad \square M$

Figure 1 DMF distribution by tooth for 12-year-old children (F = filled, DF = decayed and filled, $D=$ decayed, $M=$ missing teeth). Note: Unerupted teeth and teeth extracted for reasons other than dental caries have been excluded from the calculation of percentage. Sealed teeth were included in the count of sound teeth. 
Eastern Mediterranean Health Journal, Vol. 15, No. 4, 2009

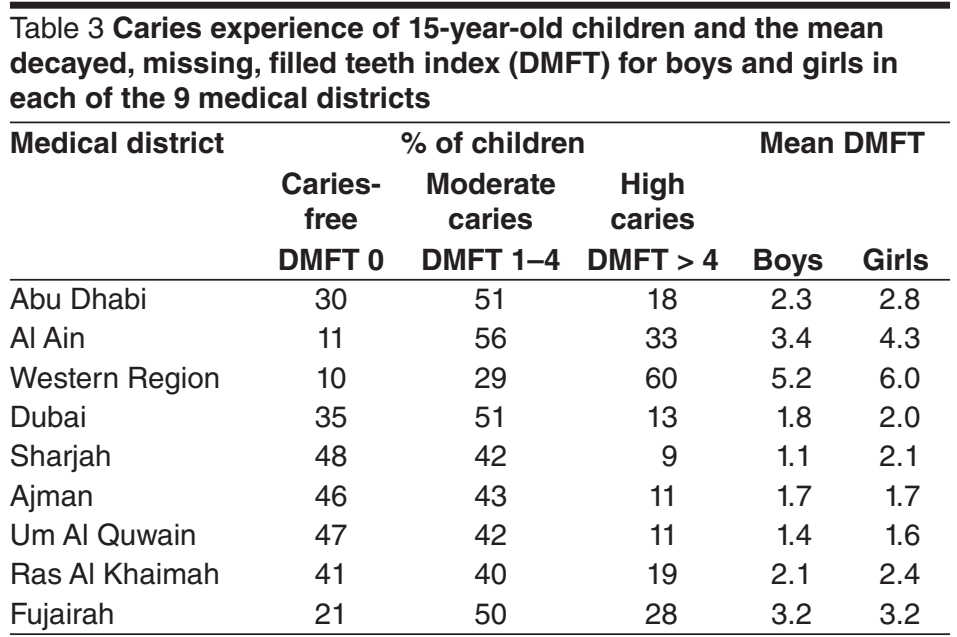

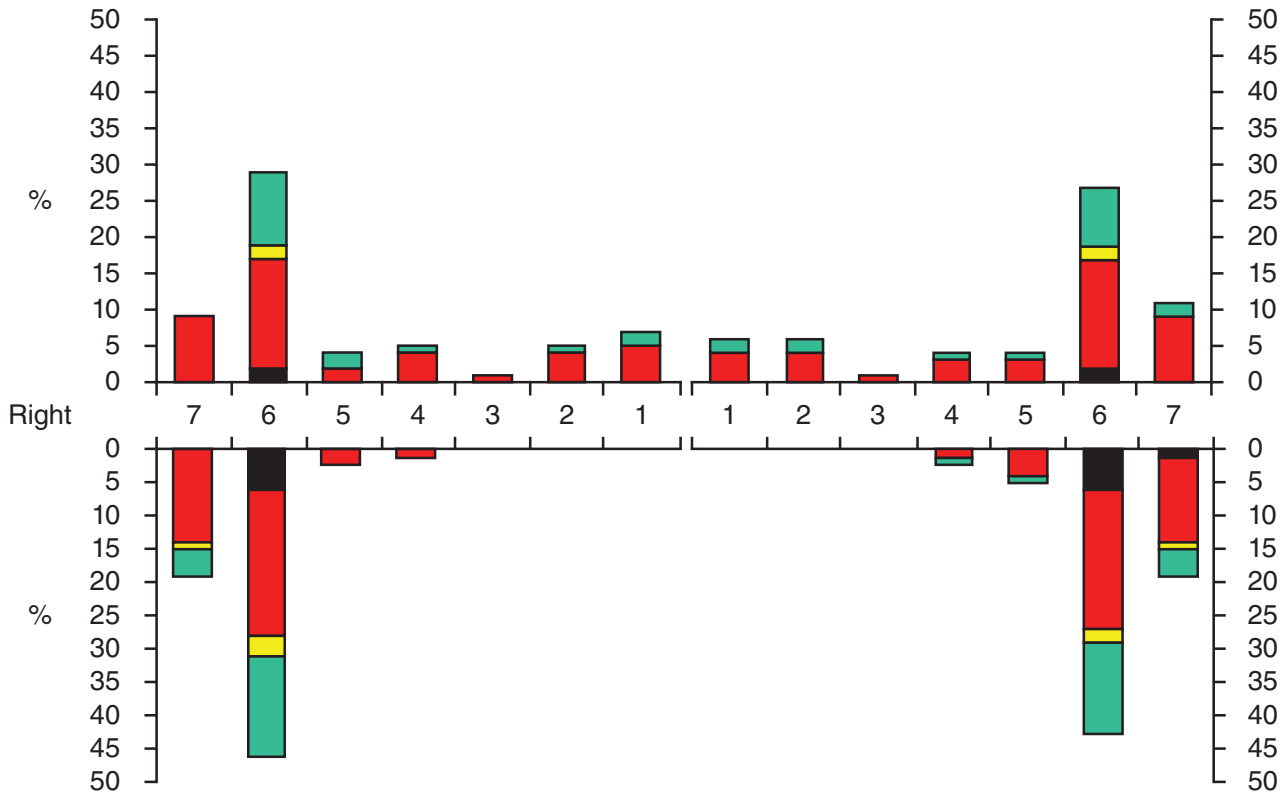

\section{$\square \mathrm{F} \quad \mathrm{DF} \quad \square \mathrm{D} \quad \mathrm{M}$}

Figure 2 DMF distribution by tooth for 15 -year-old children $(F=$ filled, $D F=$ decayed and filled, $\mathrm{D}=$ decayed, $\mathrm{M}=$ missing teeth). Note: Unerupted teeth and teeth extracted for reasons other than dental caries have been excluded from the calculation of percentage. Sealed teeth were included in the count of sound teeth.

المجلة الصحية لشرق المتوسط، منظمة الصحة العالمية، المجلد الخامس عشر، العدد ع، 9 . . 
In Western Region, a high percentage of schoolchildren $(60 \%)$ had decay in $>4$ teeth; this was only $9 \%$ in Sharjah. Almost 1 in 8 schoolchildren had experienced extraction of $\geq 1$ teeth for dental caries and about a quarter had had teeth filled. The 15-yearolds in Abu Dhabi were the most likely to have had teeth filled.

Mean DMFT 2.5 overall was recorded for 15-year-olds. The highest mean value (5.7 DMFT) was in Western Region and the lowest in Sharjah and Um Al Quwain (1.5 DMFT). In Western Region, 15-year-olds had mean 5.0 DT and 0.4 FT, while those in Abu Dhabi had mean 0.9 DT and 1.5 FT.

There was a slight tendency for girls to have higher DMFT scores; this was observed in 6 of the 9 medical districts (Table 3). The provision of treatment (FT), though, was similar in boys and girls.

UAE nationals tended to have higher DMFT values than non-UAE nationals; again, this was recorded in 6 out of 9 medical districts. Provision of care (in terms of FT) was approximately equal in UAE nationals and non-nationals.

\section{Examiner reproducibility}

Examiner reproducibility was measured by the reliability coefficient [2] calculated for
7 of the 9 examiners from re-examination of $10 \%$ of the schoolchildren. In 2 districts, the examiner did not re-examine any child. The data obtained by the 7 examiners had high reliability (reliability coefficient $=0.97$ for 12 years and 0.93 for 15 years).

\section{Dental fluorosis}

The prevalence of dental fluorosis is presented in Table 4 for 12-year-olds and in Table 5 for 15-year-olds. Data were not recorded for 12-year-olds in Al-Ain district and the average for the UAE needs to be interpreted with this in mind. For the UAE as a whole, $70 \%$ of 12 -year-old schoolchildren had no teeth with dental fluorosis (grades 0 and 1); this varied from $39 \%$ in Dubai to $99 \%$ in Abu Dhabi medical district. None of the schoolchildren had teeth with severe fluorosis (grade 5) and overall, $0.8 \%$ had 1 or more teeth graded moderate fluorosis (grade 4). Very mild fluorosis (grade 2) was common, with $20 \%$ of 12 -year-olds having 1 or more teeth with this grade. Severity of dental fluorosis was highest in Dubai and lowest in Abu Dhabi.

There were some differences between the sexes in the prevalence and severity of dental fluorosis, with mild and moderate fluorosis tending to be more prevalent in

\begin{tabular}{|c|c|c|c|c|c|}
\hline \multirow[t]{2}{*}{ Medical district } & \multicolumn{5}{|c|}{$\%$ of children with dental fluorosis: } \\
\hline & $\begin{array}{l}\text { Healthy } \\
\text { Grade } 0\end{array}$ & $\begin{array}{c}\text { Questionable } \\
\text { Grade } 1\end{array}$ & $\begin{array}{c}\text { Very mild } \\
\text { Grade } 2\end{array}$ & $\begin{array}{c}\text { Mild } \\
\text { Grade } 3\end{array}$ & $\begin{array}{c}\text { Moderate } \\
\text { Grade } 4\end{array}$ \\
\hline Abu Dhabi & 94 & 5 & 1 & 0 & 0 \\
\hline Western Region & 55 & 32 & 10 & 3 & 1 \\
\hline Dubai & 8 & 31 & 38 & 21 & 2 \\
\hline Sharjah & 8 & 53 & 30 & 7 & 3 \\
\hline Ajman & 17 & 34 & 31 & 15 & 2 \\
\hline Um Al Quwain & 43 & 33 & 22 & 3 & 0 \\
\hline Ras Al Khaimah & 21 & 29 & 43 & 7 & 0 \\
\hline Fujairah & 58 & 29 & 9 & 4 & 0 \\
\hline
\end{tabular}

Data not recorded in Al Ain district. 
boys than in girls. There was no consistent difference between UAE nationals and nonnationals in the prevalence and severity of dental fluorosis.

About $2 \%$ of 15 -year-olds had moderate fluorosis. The percentage of mild and moderate fluorosis was highest in Dubai (23\%) (similar to that for 12-year-olds). The percentage of mild and moderate dental fluorosis was next highest in Sharjah and Ras Al Khaimah (both 16\%). Little difference between boys and girls was recorded (Table 5), except in Ajman where the prevalence of mild and moderate fluorosis was higher in girls than in boys.

\section{Periodontal disease}

The periodontal disease status, as measured by the CPITN, of 15-year-old schoolchildren is given in Table 6. The CPITN was not measured in Al-Ain medical district and the average score for the UAE needs to be interpreted with this in mind. Overall in the UAE, $37 \%$ of children had healthy periodontal tissues, $15 \%$ had 1 or more sextants which bled on probing but had no calculus, and $39 \%$ had 1 or more sextants with calculus. Pocketing was not examined for this survey.
The percentage of schoolchildren with healthy periodontal tissues was lowest in Fujairah medical district and highest in $\mathrm{Aj}$ man. There was little difference in CPITN percentages between the sexes (Table 6) or between UAE nationals and non-nationals.

\section{Discussion}

This was the first national survey of oral health in the UAE. It was decided to survey schoolchildren and not adults as oral disease begins in childhood and preventive programmes are often planned and implemented at this time; sampling of children is easier than for adults; and more international comparisons can be made for children than for adults. Future national surveys are likely to include adults. Our survey included 12and 15 -years-olds because 12 years is the most common age for oral health surveys according to WHO recommendations [1] and by the age of 15 years the majority of the permanent dentition has been present in the mouth for 2 to 3 years and the children are likely to be still in school.

Mean data presented for the UAE as a whole took account of differences in district

\begin{tabular}{|c|c|c|c|c|c|c|c|c|c|}
\hline \multirow[t]{3}{*}{ Medical district } & \multicolumn{9}{|c|}{$\%$ of children with dental fluorosis: } \\
\hline & \multicolumn{3}{|c|}{$\begin{array}{c}\text { Healthy/questionable } \\
\text { Grade } 0 \text { or } 1\end{array}$} & \multicolumn{3}{|c|}{$\begin{array}{l}\text { Very mild } \\
\text { Grade } 2\end{array}$} & \multicolumn{3}{|c|}{$\begin{array}{l}\text { Mild/moderate } \\
\text { Grade } 3 \text { or } 4\end{array}$} \\
\hline & Boys & Girls & Both & Boys & Girls & Both & Boys & Girls & Both \\
\hline Abu Dhabi & 97 & 100 & 99 & 3 & 0 & 1 & 0 & 0 & 0 \\
\hline Al Ain & 72 & 80 & 76 & 14 & 14 & 14 & 15 & 6 & 10 \\
\hline Western Region & 75 & 66 & 68 & 10 & 18 & 15 & 15 & 16 & 17 \\
\hline Dubai & 64 & 49 & 53 & 9 & 30 & 24 & 27 & 21 & 23 \\
\hline Sharjah & 48 & 48 & 47 & 35 & 38 & 36 & 18 & 15 & 17 \\
\hline Ajman & 88 & 66 & 72 & 10 & 17 & 15 & 2 & 17 & 13 \\
\hline Um Al Quwain & 66 & 75 & 73 & 32 & 17 & 22 & 2 & 8 & 5 \\
\hline Ras Al Khaimah & 50 & 49 & 50 & 36 & 35 & 35 & 14 & 17 & 15 \\
\hline Fujairah & 96 & 86 & 90 & 2 & 10 & 7 & 2 & 4 & 3 \\
\hline
\end{tabular}

المجلة الصحية لشرق المتو سط، منظمة الصحة العالمية، المجلد الخامس عشر، العدد ع، 9 •. 


\begin{tabular}{|c|c|c|c|c|c|c|c|c|c|}
\hline \multirow[t]{3}{*}{ Medical district } & \multicolumn{9}{|c|}{$\%$ of children with periodontal status: } \\
\hline & \multicolumn{3}{|c|}{ Healthy } & \multicolumn{3}{|c|}{ Bleeding } & \multicolumn{3}{|c|}{ Calculus } \\
\hline & Boys & Girls & Both & Boys & Girls & Both & Boys & Girls & Both \\
\hline Abu Dhabi & 44 & 60 & 52 & 35 & 20 & 28 & 21 & 20 & 21 \\
\hline Al Ain & 42 & 55 & 49 & 4 & 1 & 3 & 54 & 44 & 48 \\
\hline Dubai & 52 & 56 & 55 & 18 & 7 & 10 & 30 & 37 & 35 \\
\hline Sharjah & 21 & 37 & 29 & 28 & 35 & 32 & 51 & 28 & 39 \\
\hline Ajman & 57 & 59 & 59 & 14 & 17 & 16 & 29 & 24 & 25 \\
\hline Um Al Quwain & 47 & 32 & 37 & 25 & 22 & 23 & 28 & 46 & 40 \\
\hline Ras Al Khaimah & 31 & 26 & 27 & 5 & 10 & 9 & 64 & 64 & 64 \\
\hline Fujairah & 19 & 13 & 15 & 6 & 8 & 7 & 76 & 79 & 78 \\
\hline
\end{tabular}

size. This is a common procedure as it limits the number of schools visited to an acceptable level. It should be noted, however, that in some medical districts, the random selection of schools resulted in an imbalance of boys and girls, and stratification of schools by sex may be desirable in the future. In practice, in this survey, there was little difference in oral disease between boys and girls. The very low rate of non-participation (non-consent or absence from school) is a welcome feature of this survey.

Some other diseases or defects were excluded (e.g. oral cleanliness, malocclusion, dental trauma and dental enamel defects other than fluorosis) in this survey as they are of lesser importance or are difficult to record, and limiting the burden on inexperienced examiners was considered important.

There are very few dentists trained in epidemiology in the UAE. For practical reasons, it was decided to have 1 examiner from each of the 9 medical districts. It was very important that these examiners conformed to a single standard and that this standard conformed to that of the WHO. The 7 examiners who undertook re-examination of subjects demonstrated a high level of reliability of data. In future surveys, verify- ing diagnostic standards between examiners would be desirable: the establishment of an oral epidemiology training unit would help considerably. This might avoid the non-recording of dental fluorosis which occurred in 1 district in this survey.

The mean DMFT for 12- and 15-yearold schoolchildren in the UAE was 1.6 and 2.5. Comparing similar surveys in other countries such as China showed a mean DMFT of 1.0 and 1.4 for the same age groups [4]. In India the mean DMFT for 12-year-old schoolchildren was 0.5 [5], whereas it was 4.6 for the same age group in Vietnam [6]. In a survey conducted in Lebanon, mean DMFT for 12- and 15-yearolds were 5.0 and 7.7 respectively [7], and in Nigeria mean DMFT for the same groups was 0.7 and 1.3 [8].

There is an extensive databank held by WHO on the caries experience of 12year-olds. Comparing mean DMFT from countries geographically close to the UAE and selected other countries, the 1.6 DMFT for the UAE is similar to those recorded in neighbouring countries (Oman 1.5, Saudi Arabia 1.7 and Bahrain 1.4). It is, though, higher than values currently recorded in northern Europe. 
The 15-year-olds in the UAE had mean 2.5 DMFT in this survey. Values for the same age in sme neighbouring countries were 2.5 DMFT in Bahrain, 2.8 DMFT in Jordan, 3.2 DMFT in Oman, 3.6 DMFT in Kuwait and 3.8 DMFT in Saudi Arabia [9].

If the "questionable" grade of dental fluorosis is included within the "healthy" grade, the prevalence of dental fluorosis was $32 \%$ in 12 -year-olds and $30 \%$ in 15 -year-olds in this survey. In the only previous study in the UAE, a small study of 59 children, $18 \%$ of 15 -year-olds had dental fluorosis [unpublished report, 1991, K. Cowles].

There have been no previous surveys of periodontal disease in the UAE. However, the WHO maintains a databank of CPITN values, and information on 15-19-year-olds from countries geographically close to the UAE and selected other countries. The percentage of 15 -year-olds with healthy periodontal tissues $(41 \%)$ was higher than in other countries in the region; the percentage of 15 -year-olds with bleeding (16\%) or calculus (43\%) was also better (lower) than in many other countries. Periodontal pockets were not examined for in our survey as low prevalence could be expected at the age of 15 years and "false pocketing" occurs (due to partial tooth eruption) in adolescence. This decision should be reconsidered when planning the next survey.

Overall, the rates of caries in the permanent dentition, dental fluorosis and periodontal disease were similar to many other countries. However, these levels indicate considerable oral morbidity, which demands attention for untreated dental caries.

Although the fluoride concentration in drinking water in the Emirates is generally low, much caries prevention is fluoridebased and recording the prevalence and severity of dental fluorosis seemed to be a wise precaution. Planning future surveys should consider the inclusion of adults.

\section{Conclusions}

Regarding the implications for the Ministry of Health, in spite of remarkable progress in the provision of dental health services in the UAE, dental caries remains a public health problem in young children. The low prevalence of periodontal disease and dental fluorosis in schoolchildren aged 12 and 15 years should not be considered an indication of good oral health in these children: a low prevalence of periodontal diseases is expected at this age.

Coordinated epidemiological studies should be carried out every 5 years. Resources such as well-trained staff and an adequate budget should be available to secure the success of such investigations.

School-based preventive programmes should be encouraged and supported, and any national preventive strategy to control dental caries should take into account the trends in dental caries. Local legislation in each Emirate can play a major role in reducing the risk of dental diseases.

\section{Acknowledgements}

The dental department extends its gratitude to the Ministry of Education and the directors of the medical districts for their cooperation in facilitating the work of the survey teams. 


\section{References}

1. Oral health surveys: basic methods, 4th ed. Geneva, World Health Organization, 1979.

2. Rugg-Gunn AJ, Holloway PJ. Methods of measuring the reliability of caries prevalence and incremental data. Community dentistry and oral epidemiology, 1974, 2:287-94.

3. Dean HT. Classification of mottled enamel diagnosis. Journal of the American Dental Association, 1934, 21:1421.

4. Wang HY et al. The second national survey of oral health status of children and adults in China. International dental journal, 2002, 52(4):283-90.

5. David $\mathrm{J}$ et al. Dental caries and associated factors in 12-year-old schoolchildren in Thiruvananthapuram, Kerala, India. International journal of paediatric dentistry, 2005, 15(6):420-8.
6. Tayanin GL, Ramanathan J, Bratthall D. Caries prevalence and some caries related factors for 12-year-old children from Vietiane and Luang Prabang provinces in Lao People's Democratic Republic. Odonto-stomatologie tropicale, 2002, 25(98):19-26.

7. Hussain SA et al. Oral health in Lebanon: a pilot pathfinder survey. Eastern Mediterranean health journal, 1996, 2:299-303.

8. Adegbembo AO, El-NadeefM, Adeyinka A. National survey of dental caries status and treatment needs in Nigeria. International dental journal, 1995, 45:35-44.

9. WHO global infobase. World Health Organization [online database] (http://www. who.int/infobase/reportviewer.aspx?rptco $\mathrm{de}=\mathrm{ALL} \&$ surveycode $=160022 \mathrm{a} 1 \& \mathrm{dm}=6$, accessed 25 November 2008).

\section{Oral health facts}

- The most common oral diseases are dental cavities and periodontal (gum) disease.

- $60 \%-90 \%$ of schoolchildren worldwide have dental cavities.

- Severe periodontal (gum) disease, which may result in tooth loss, is found in $5 \%-20 \%$ of middle-aged adults; the rate varies across geographical regions.

- Incidence of oral cancer ranges from one to 10 cases per 100000 population in most countries.

- Birth defects such as cleft lip and palate occur in around one per 500-700 of all births; the birth prevalence rate varies substantially across ethnic groups and geographical areas.

Source: WHO Fact sheet, No. 318 February 2007

المجلة الصحية لشرق المتوسط، منظمة الصحة العالمية، المجلد الخامس عشر، العدد ع، 9 + • 